\title{
What is Happening to Used Car Prices in Turkey? Evidence From Hedonic Price Model (Hpm)
}

\author{
Mustafa KOÇ* \\ Nurcan KOSTAK ${ }^{* *}$
}

\begin{abstract}
With the Covid 19 pandemic, many sectors on a global scale have been affected by this situation. In Turkey, automobile industry faced with high price volatilities and used car prices increased drastically, indeed, they surged brand new ones. Thus, the purpose of this study is examining the used car prices on two different time May 2020 and Mar 2021 by Hedonic Price Model (HPM). For this purpose, cross-sectional linear regression method is applied to price and hedonic characteristics of Renault Megane and Volkswagen Passat as two of top 10 most sold car model in 2020 in Turkey. Equipment, year, mileage, transmission, fuel, color and location of the seller variables were applied to determine the effect on the price of the used car. On both dates 2018-2019-2020 model year cars are used for comparison purposes. According to test results the equipment, year, mileage, transmission and fuel variables and constant term for each model are statistically significant. The color variables and variables represent the location of the seller are less successful in explanation.

Keywords: used car prices, price fluctuation, hedonic price model, automobile industry, Turkey
\end{abstract}

\section{Türkiye'de İkinci El Araç Fiyatlarına Ne Oluyor? Hedonik Fiyat Modeli (Hpm) Üzerinden Bulgular}

ÖZ

Covid 19 pandemisiyle birlikte küresel çapta pek çok sektör bu durumdan etkilenmiştir. Türkiye'de otomobil sektörü ise yüksek fiyat dalgalanmalarının yaşandığı ve ikinci el araç fiyatlarının önemli ölçüde yükseliş gösterdiği hatta sıfır araç fiyatlarının önüne geçtiği tespit edilmiştir. Bu sebeple bu çalışmanın amac1, Hedonic Fiyat Modeli (HPM) ile Mayıs 2020 ve Mart 2021 olmak üzere iki farklı zaman diliminde ikinci el araba fiyatlarını incelemektir. Bu amaçla, 2020 yılında Türkiye'de en çok satılan ilk 10 otomobil modelinden ikisi olan Renault Megane ve Volkswagen Passat'ın fiyatları ve hedonik özelliklerine kesitsel doğrusal regresyon yöntemi uygulanmıştır. İkinci el arabanın fiyatı üzerindeki etkiyi belirlemek için donanım, yıl, kilometre, şanzıman, yakıt, renk ve satıcının konumu değişkenleri kullanılmıştır. Karşılaşı̧ıma yapabilmek adına her iki tarihte de 2018-2019-2020 model yılı arabalar kullanılmıştır. Test sonuçlarına göre her bir model için donanım, yıl, kilometre, şanzıman, yakıt değiş̧kenleri ve sabit terim istatistiksel olarak anlamlıdır. Renk değişkenleri ve satıcının konumunu gösteren değişkenler araç fiyatlarını açıllamada daha az başarılıdır.

Anahtar Kelimeler: ikinci el araba fiyatları, fiyat dalgalanması, hedonik fiyat modeli, otomobil sektörü, Türkiye

\section{Introduction}

Covid-19 pandemic first occurred in the first months of 2020 and first detected on March 11, 2020 in Turkey. Same day World Health Organization also stated the Covid-19 virus as pandemic (World Health Organization, 2020). After this occurrence, our daily life and habits have changed drastically. Governmental actions and precautions manipulated our daily routines. After several months we have tried to back to our daily life due to economic issues on the first days of June 2020.

Health is not the only industry affected by the Covid-19, pandemic has also affected tourism (Gössling, Scott, \& Hall, 2020), information technology (Park, Choi, \& Ko, 2020), and automobile industry (Barrero, Bloom, \& Davis, 2020). For example, people did not want to utilize the public transportation rather they preferred private cars after occurrence of Covid-19 (Bexter, 2020). In Turkey, vending used cars or brandnew ones have continued during pandemic period in a different manner we used to do. For example, a step of visual inspection of a car cannot be managed during the curfew period. But people wanted to sell or buy a car under these circumstances. Thus, several other methods have arisen such as virtual inspection (like visual inspection via several video call applications) or arranging appraisement firms you decided to inspect the candidate car brought by the seller. These several methods occurred during the pandemic in order to maintain the trust between the buyer and seller to realize the vending process.

\footnotetext{
* Ress. Asst. Ph.D., Sakarya University, mustafakoc@sakarya.edu.tr

** Ress. Asst. Ph.D., Sakarya University, nsimsek@sakarya.edu.tr

Makalenin Gönderim Tarihi: 05.04.2021; Makalenin Kabul Tarihi: 10.10.2021
} 
Besides used cars, there are several issues with brand new ones. As mentioned above, in Turkey demand for the new cars decreased for the first half of 2019, thus brands did not foresee the increasing demand for new cars in the last quarter of 2019 (Philkotse, 2019). Thus, used car prices increased above new ones due to the lack of supply in the first months of 2020. However, after several months after March like sometime after May 2020, brands brought new cars which are expected to decrease the used car prices by increasing competition in the car industry (Lambin, 1970). The used car prices have never decreased, though. The reason behind this showed up as manipulation conducted by used car vendors. From their point of view, they bought used cars for a certain price during the pandemic and did not want to face the loss. Thus, they have prepurchased all the newly brought cars before anybody and put them into their vending stores with relatively higher prices. When you have gone to branches of brands to purchase a new car, you would leave with empty hands since all cars had already been sold. This behavior can be called 'sly as a fox' (or profiteering as the most known) which is the most common issue among both buyer and seller (Wang and Zhang, 2008).

The expectation of abnormal return and misdemeanor among people has vital effects on the process of vending cars. First, it is harmful to trust in the vending process which will eventually negatively affect society. Governmental regulations about these issues are usually belated and manipulators have already produced different covetous methods. Second, it has negative effects on the economy. There are literally enormous tax losses due to not monitoring the process and abnormal returns (Branch, 1977). The competition in the used car industry has also been manipulated and the price of a car cannot be determined under a free-market economy (Friedman, 2007).

Besides both new and used car prices are increasing in Turkey, there are several other situations in the prices in different countries. For instance, on the one hand car prices decreased and car industry stalled in USA during the pandemic (Szczesny, 2020); on the other hand, the car prices surged in Australia due to increasing demand for private transportation (Bexter, 2020). According to Statista (2020), the average price of passengers cars in Turkey in 2019 was 30,309 (euros) which was 25\% higher than the EU-13 countries and had almost same average with EU-28 countries. However, gross domestic product per capita was 34,913 US\$ and 9,126 US\$ in European Union and Turkey, respectively (The World Bank, 2020).. The significantly higher price for passenger car according to average income of a citizen in Turkey compared to European countries brought us to investigate this issue.

Thus, this study will examine the possible reasons behind the unexpected increase in the used-car prices in Turkey during a pandemic crisis. The used car industry, its components \& and functions, and issues related to this industry will be addressed in the scope of this study. The price movements of used cars will be investigated with Hedonic Price Model (HPM) which assumes the price is manipulated only by internal factors such as quality or equipment of the car. The evaluation and comments will be given specifically to Turkey.

\section{What is happening to car prices in Turkey?}

Nowadays, abnormal events are occurring in the prices of used cars in Turkey. The major observation is that used car prices have become higher than the brand-new ones and the second one is an enormous increase in used car prices in the last few years. Though this event seems absurd, there are significant factors affecting the used car prices. One is the supply of brand-new cars. There was a shortage in the supply of new cars in the first months of 2020. The reason behind this issue is stemming from the excessive demand in the second half of 2019. Suppliers didn't foresee the increased demand in the last quarter of 2019 to be prepared for the first quarter of 2020. This explains one side of why used car prices are higher than the new ones. The second reason is the drastic increase in used car prices due to an increase in the prices of brand-new ones. 


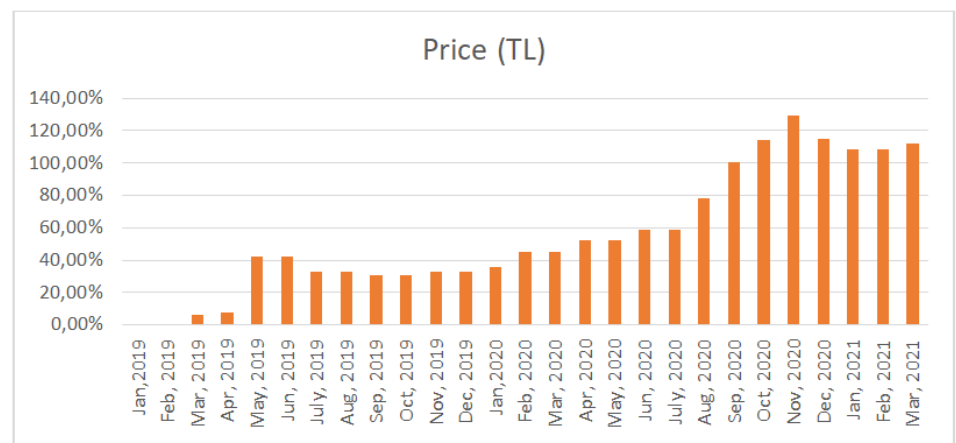

Figure 1. Historical Prices of Specific Model of Brand X (TL)

Source: Otokokpit (2020). https://www.otokokpit.com/volkswagen-kasim-2019-fiyat-listesi-aciklandi/

Note: Values in the chart are calculated as the percentage change by the base month of Jan 2019. The monthly price values are retrieved from the above online resource, then graphed trough the excel. The above link represents the one specific monthly price data.

The Figure 1 shows the purchasing prices of a specific model of Brand $X$ which are the real numbers. The values at the graph are the percentage change of monthly sale price based on January 2019. This simply means that if the purchasing price of the car is $1,000 \$$ on January 2019 , then the price will be 2,200 \$ in March 2021 (since the graph value of March 2021 is 110\%). The enormous increase in April 2019 and September 2020 can also be visible without any explanation. There used to be a discount on the Special Consumption Tax on the cars and it has ended on June $30^{\text {th }}, 2019$. The increase in the prices in May 2019 shows the increase in the list price of the car made by the brand, not the purchasing price of a customer. Furthermore, the Special Consumption Tax rate is increased on September 1st 2020. The meaning of special consumption tax and its effects on the purchasing price of a car will be discussed later.

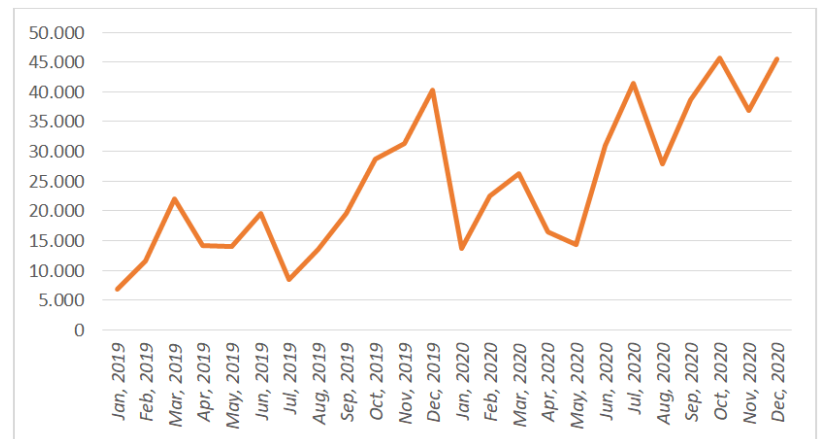

Figure.2 Automobile Sales in Turkey

Source: Automotive Distributors' Association (2020)

Note: Values in the figure are the real number of sales for each month.

The Figure 2 shows the number of automobile sales from January 2019 to December 2020 in Turkey. There is a visible fluctuation in the sales line and sales have the pike point in December 2019, July, October, and December 2020 during this period. The Covid-19 pandemic has first occurred in Turkey in March 2020 and the decrease of brand-new car sales at that time can be seen from the graph as well.

The third reason is that unlike many European countries, purchasing a car is a kind of financial investment for Turkish citizens, though this behavior did not exist in the 2000s. The drastic increase in car prices in Turkey has occurred mainly for the last decade. 


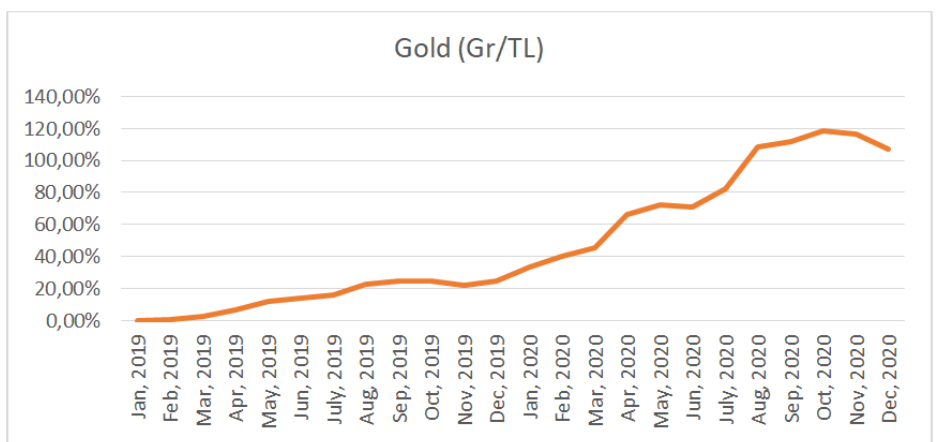

Figure.3 Prices of Gold between Jan 2019 to Dec 2020

Source: Bloomberg HT. (2020). https://www.bloomberght.com/altin

Note: Values in the graph are calculated as the percentage change by the base month of Jan 2019.

The above graph shows the prices of gold (grams) in TL (Turkish Lira) from January 2019 to December 2020. The values at the graph are the percentage change calculated by the base month of January 2019. As seen on the graph, after January 2020, there is an extraordinary increase in the gold prices that it has almost doubled its initial purchasing price.

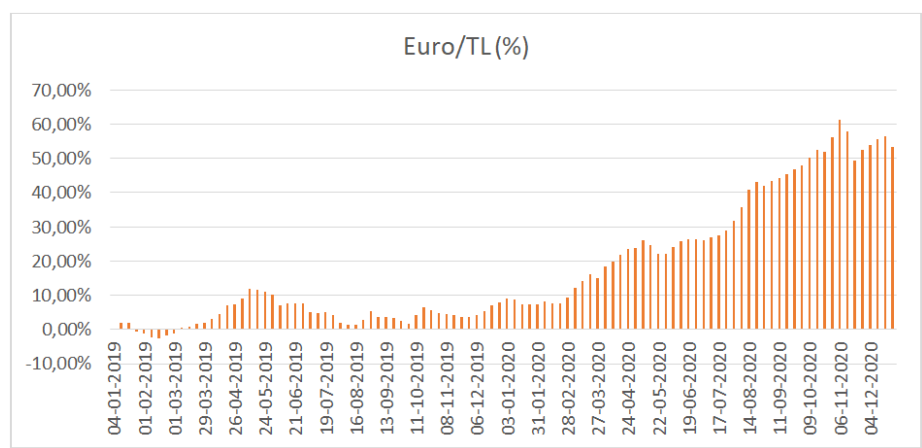

Figure.4 Euro/TL Currency Change (\%)

Source: Central Bank of The Republic of Turkey (2020)

https://evds2.tcmb.gov.tr/index.php?/evds/serieMarket/\#collapse_2

Note: Values in the graph are weekly data and calculated as the percentage change by the base value of first week of Jan 2019.

\section{Used Car Industry in Turkey}

Like gold, the Euro currency has also increased its value during January 2019- December 2020 period. The values in Figure 4 are the percentage change of the currency calculated by the base value of the first week of January 2019. The Turkish Lira has inflated against Euro currency after the first occurrence of the Covid-19 case in Turkey. The general attitude during the high inflation period is just leaving the local currency which means in this case foreign currency or gold. Both gold and Euro showed an excessive increase in value during the pandemic. Thus, the simple and easiest hypothesis comes forth that people who possess such kind of values have increased their wealth and who do not has become poorer. In this case, the increase in wealth is also not stemming from any production or working. Thus, herd psychology obviously produced 'overvalue behavior' about anything in their inventory. The overvalue behavior means the valuation of any item in your possession above its actual selling price. This behavior did not occur on real estates, because people tend to prefer more liquid assets during the uncertainty periods (Lucas and Stokey, 2011). So, the price movements of used car prices can simply rely on this issue.

Before going deeper into the price movements of the used car industry in Turkey, let us have a look at the general framework of the used car industry.

There are two major participants in the process of vending cars: Buyers and Sellers. In a high inflation environment, sellers will not be able to replace their cars with the same amount of money. That briefly means you will not buy how much you sell. From a buyer's perspective, there are two different situations: 
the financial capability to buy with its own capital or using external sources. If the buyer would buy with its capital means it will only face the chance cost of a possible investment. If it uses external financial sources, it will deal with the interest burden of that process.

To understand the price movements in the used car industry in Turkey, one must understand the psychology of its every component (buyers, sellers, appraisement firms, and government). Thus, every single detail in vending used cars in Turkey gains its importance due to this reason.

\section{Prices of Used and Brand-New Cars in Turkey}

Before going through used car prices, we have to closely look at the new car prices in Turkey. The price of a new car consists of 'the base price (manufacturer's price)', 'special consumption tax', 'valueadded tax', 'motor vehicles tax', 'official fees for traffic - registration and license procedures' and 'service fees for traffic - registration and license procedures'.

The base price (which is also the import price) reflects how much the manufacturer of the car will gain after the purchasing process. It is obviously decided by the manufacturer.

The special consumption tax is a percentage of the base price which is in the control of the Ministry of Finance. The percentage of these tax changes according to the base price. It has the most effect on the final price of a car and has quite an interesting history for the last 3 years.

The value-added tax is a percentage of the sum of the base price and the special consumption tax and is $18 \%$ for all cars (In here, as you notice we are calculating tax of tax.).

The motor vehicle tax is a semi-annual payment as long as you keep the car in your possession, and obviously, you are paying the current semi year motor vehicle tax during the purchasing process. The amount of the motor vehicle tax is highly related to the model year and the engine volume of the car. It is decided by the Ministry of Finance, generally increased by 25\% annually and collected in two equal payments (the first one in January, the second one in July).

Official fees for traffic - registration and license procedures are the payments for the official papers of the car as indicated in the name and paid the authorities. It is also decided by the Ministry of Finance and fixed for all cars.

Service fees for traffic - registration and license procedures are the payments for the one who is managing your traffic - registration and license procedures instead of you. It is given to the seller firm (the branch of the brand) and the amount of this fee is decided by the seller.

So, these six components are creating the purchasing price of a brand-new car. At this point, it will be better to follow these stages on a real-life example which is shown in Table 1 (derived from one specific brand webpage from April 2020 prices) (As indicated previously, special consumption tax on brand new cars has been changed during our research. Thus, both April 2020 and September 2020 car prices of a specific brand are shown in Table 1 for comparison): 
Table 1. Components of Purchasing Price of a Brand-New Car in Turkey

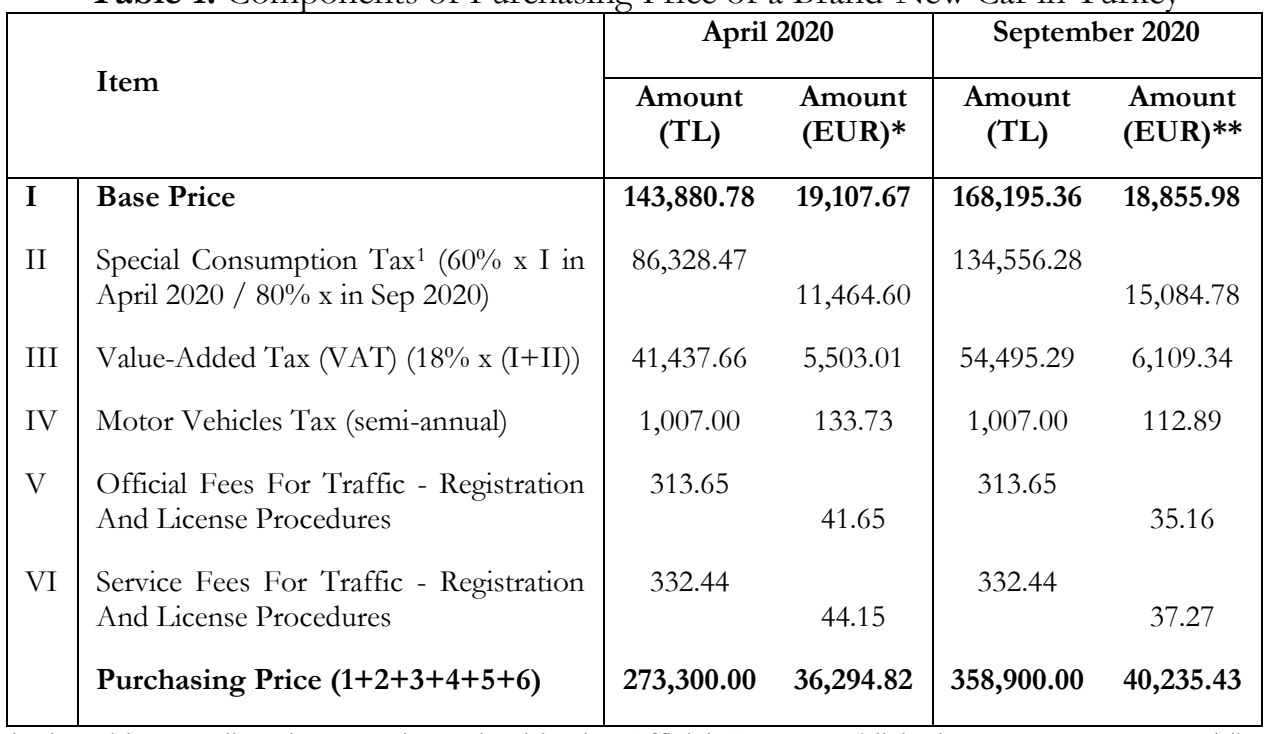

Note: It is the table regarding the rates determined in the Official Gazette published on August 30, 2020. The car given its price on the table has a $1.5 \mathrm{~L}$ engine and it is the 2020 model. Since its base price is above 120,000 TL and it has a $1.5 \mathrm{~L}$ engine, the special consumption tax rate for this specific car was $60 \%$ of the base price. According to the special consumption tax rate adjustments its tax rate has become $80 \%$ of the base price.

* These calculations have been made using the exchange rate of EURO/TL which is 7.53 on April 30, 2020, and 8.92 on September 21 , 2020. https://www.tcmb.gov.tr/wps/wcm/connect/EN/TCMB+EN/Main+Menu/Statistics/Exchange+Rates

Source: 1

\begin{tabular}{|c|c|c|c|c|}
\hline \multicolumn{5}{|c|}{$\begin{array}{c}\text { Calculation Special Consumption Tax and Value-Added Tax For } 2020 \text { Model Brand-New } \\
\text { Automobiles }\end{array}$} \\
\hline & Cylinder Volume & Sale Price (Without Tax) & $\begin{array}{c}\text { Special } \\
\text { Consumption Tax }\end{array}$ & $\begin{array}{l}\text { Value-added } \\
\operatorname{tax}\end{array}$ \\
\hline \multirow{6}{*}{ 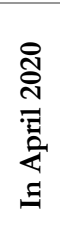 } & Less than $1600 \mathrm{~cm}^{3}$ & Up to $70.000 \mathrm{TL}$ & \begin{tabular}{|c|}
045 \\
\end{tabular} & $\% 18$ \\
\hline & Less than $1600 \mathrm{~cm}^{3}$ & Between $70.000 \mathrm{TL}$ and $120.000 \mathrm{TL}$ & $\% 50$ & $\% 18$ \\
\hline & Less than $1600 \mathrm{~cm}^{3}$ & Above $120.000 \mathrm{TL}$ & $\% 60$ & $\% 18$ \\
\hline & $1600 \mathrm{~cm}^{3}<2000 \mathrm{~cm}^{3}$ & Up to $170.000 \mathrm{TL}$ & $\% 100$ & $\% 18$ \\
\hline & $1600 \mathrm{~cm}^{3}<2000 \mathrm{~cm}$ & Above $170.000 \mathrm{TL}$ & $\% 110$ & $\% 18$ \\
\hline & Greater than $>2000 \mathrm{~cm}^{3}$ & Unlimited & $\% 160$ & $\% 18$ \\
\hline \multirow{6}{*}{ 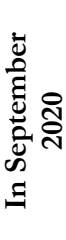 } & Less than $1600 \mathrm{~cm}^{3}$ & Up to $85.000 \mathrm{TL}$ & $\% 45$ & $\% 18$ \\
\hline & Less than $1600 \mathrm{~cm}^{3}$ & Between $85.000 \mathrm{TL}$ and $130.000 \mathrm{TL}$ & $\% 50$ & $\% 18$ \\
\hline & Less than $1600 \mathrm{~cm}^{3}$ & Above $130.000 \mathrm{TL}$ & $\% 80$ & $\% 18$ \\
\hline & $1600 \mathrm{~cm}^{3}<2000 \mathrm{~cm}^{3}$ & $\mathrm{Up}$ to $170.000 \mathrm{TL}$ & $\% 130$ & $\% 18$ \\
\hline & $1600 \mathrm{~cm}^{3}<2000 \mathrm{~cm}$ & Above $170.000 \mathrm{TL}$ & $\% 150$ & $\% 18$ \\
\hline & Greater than $>2000 \mathrm{~cm}^{3}$ & Unlimited & $\% 220$ & $\% 18$ \\
\hline
\end{tabular}

In April 2020, the price of the car was 273,300.00 TL which was 36,294.82 EUR according to the exchange rate on April 30, 2020 (EURO/TL=7.53). The price has increased to 358,900.00 TL which has become 40,235.43 EUR according to the exchange rate on September 21, 2020 (EURO/TL=8.92). This clearly shows that the purchasing price has increased by $31 \%$ in TL, $10 \%$ in EUR. The amount of increase in car prices goes to the government as tax. Furthermore, the manufacturer price has increased from 143,880.78 TL to $168,195.36$ TL, but it decreased from 19,107.67 EUR to 18,855.98 EUR when converted into EURO currency. This means that there are a $16 \%$ increase in income for the manufacturer for Turkish Lira and $-1,3 \%$ income loss for Euro currency. Briefly, according to the Turkish Lira, all components of a car price have increased after-tax adjustments for a Turkish citizen. However, according to the Euro currency, the manufacturer price has decreased while the purchasing price was increasing. For comparison, the most vital observation is that the brand-new car prices of the specific model of the one 
brand on two different countries are investigated that in Turkey the price of that specific car is 58,778.03 Euro while it is 40,490 Euro in manufacturer's country. Besides the currency transformation or ignoring the purchasing power of an individual which means that minimum wage on that country is 9.35 Euro per hour (Reuters, 2020) while it is 10.22 TL (1.14 Euro) per hour in Turkey (calculated by the 225 hours per one month), the price of this specific car is significantly higher than the car in where it is manufactured.

According to the purchasing price of the car, $48 \%$ of the purchasing price of a brand-new car is briefly a tax burden for a buyer. The manufacturer of the car only gains 52\% for each sold car. After a special consumption tax adjustment in September 2020, the tax burden for that specific car has increased to $53 \%$. Clearly, the manufacturer share for each sold car has decreased from $52 \%$ to $47 \%$. For another example, let us look at two different cars of the same brand with two different engine types. And to evaluate these two cars assume they have both the same base price as in the previous example (in reality obviously they will have different base prices.)

Table 2. The comparison of purchasing price of the cars with same base price but different engine volumes.

\begin{tabular}{|c|c|c|c|c|c|c|}
\hline & & Item & $\begin{array}{l}\text { Amount } \\
(2.0 \mathrm{~L}) \mathrm{TL}\end{array}$ & $\begin{array}{c}\text { Amount } \\
(3.0 \mathrm{~L}) \mathrm{TL}\end{array}$ & $\begin{array}{l}\text { Amount } \\
\text { (2.0L) EUR* }\end{array}$ & $\begin{array}{l}\text { Amount } \\
\text { (3.0L) EUR* }\end{array}$ \\
\hline \multirow{7}{*}{ 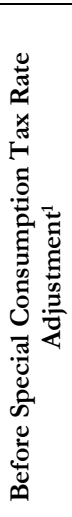 } & $\mathbf{I}$ & Base Price & $143,880.78$ & $143,880.78$ & $19,107.67$ & $19,107.67$ \\
\hline & II & $\begin{array}{l}\text { Special Consumption Tax } \\
(100 \% \times \text { I for } 2.0 \mathrm{~L})(160 \% \times \mathrm{I} \text { for } 3.0 \mathrm{~L})\end{array}$ & $143,880.78$ & $230,209.24$ & $19,107.67$ & $30,572.28$ \\
\hline & III & Value-Added Tax (VAT) $(18 \%$ x (I+II)) & $51,797.08$ & $67,336.20$ & $6,878.76$ & $8,942.39$ \\
\hline & IV & Motor Vehicles Tax (semi-annual) & $5,603.00$ & $10,741.00$ & 744.09 & $1,426.43$ \\
\hline & $\mathrm{V}$ & $\begin{array}{l}\text { Official Fees For Traffic - Registration } \\
\text { And License Procedures }\end{array}$ & 313.65 & 313.65 & 41.65 & 41.65 \\
\hline & VI & $\begin{array}{l}\text { Service Fees For Traffic - Registration And } \\
\text { License Procedures }\end{array}$ & 332.44 & 332.44 & 44.15 & 44.15 \\
\hline & & Purchasing Price $(1+2+3+4+5+6)$ & $345,807.73$ & $452,813.31$ & $45,924.00$ & $60,134.57$ \\
\hline
\end{tabular}

\begin{tabular}{|c|c|c|c|c|c|c|}
\hline & & $\begin{array}{l}\text { After Special Consumption Tax Rate } \\
\text { Adjustment }^{2}\end{array}$ & & & & \\
\hline \multirow{7}{*}{ 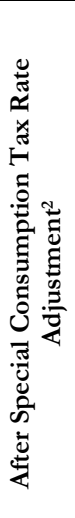 } & $\mathbf{I}$ & Base Price & $143,880.78$ & $143,880.78$ & $19,107.67$ & $19,107.67$ \\
\hline & II & $\begin{array}{l}\text { Special Consumption Tax } \\
(130 \% \text { x I for } 2.0 \mathrm{~L})(220 \% \times \text { I for } 3.0 \mathrm{~L})\end{array}$ & $187,045.01$ & $316,537.72$ & $24,839.98$ & $42,036.88$ \\
\hline & III & Value-Added Tax (VAT) $(18 \%$ x (I+II)) & $59,566.64$ & $82,875.33$ & $7,910.58$ & $11,006.02$ \\
\hline & IV & Motor Vehicles Tax (semi-annual) & $5,603.00$ & $10,741.00$ & 744.09 & $1,426.43$ \\
\hline & $\mathrm{V}$ & $\begin{array}{l}\text { Official Fees For Traffic - Registration } \\
\text { And License Procedures }\end{array}$ & 313.65 & 313.65 & 41.65 & 41.65 \\
\hline & VI & $\begin{array}{l}\text { Service Fees For Traffic - Registration And } \\
\text { License Procedures }\end{array}$ & 332.44 & 332.44 & 44.15 & 44.15 \\
\hline & & Purchasing Price $(1+2+3+4+5+6)$ & $396,741.53$ & $554,680.92$ & $52,688.12$ & $73,662.80$ \\
\hline
\end{tabular}

Note: The cars given its imaginary prices on the table have $2.0 \mathrm{~L}$ and $3.0 \mathrm{~L}$ and have both the same base prices (assumably).

${ }^{1}$ The Special Consumption Tax rate is $100 \%$ for $2.0 \mathrm{~L}$ and $160 \%$ for $3.0 \mathrm{~L}$ as announced by the authorities in April 2020. 2020.

${ }^{2}$ The Special Consumption Tax rate is $130 \%$ for $2.0 \mathrm{~L}$ and $220 \%$ for $3.0 \mathrm{~L}$ as announced by the authorities in September

Motor Vehicles Tax is depending on several things, but it is calculated according to parameters in the official announcement of tax calculations as if these are the real-life example of cars. 
* These calculations have been made using the exchange rate of EURO/TL which is 7.53 on April 30, 2020. Source: https://www.tcmb.gov.tr/wps/wcm/connect/EN/TCMB+EN/Main+Menu/Statistics/Exchange+Rates

According to the Table 2, for the car with a $2.0 \mathrm{~L}$ engine, the total tax burden for a buyer was $59 \%$ in April 2020 which means the manufacturer of a car gains only $41 \%$ of the purchasing price. Then, the tax burden has become \%63 in September 2020 if we assume car manufacturing price remained the same and manufacturers share has decreased to $37 \%$. For the car with a $3.0 \mathrm{~L}$ engine, the total tax burden for a buyer was 68\% in April 2020 which means the manufacturer of a car gains only 31\% of the purchasing price. Then, the tax burden has become \%73 in September 2020 if we assume car manufacturing price remained the same and manufacturers share has decreased to $27 \%$. This tragic scene can be summarized that in September 2020 if one Turkish citizen wants to purchase a brand-new car with a $3.0 \mathrm{~L}$ engine, $27 \%$ of the price goes to the producer of the car and $73 \%$ goes to the government as tax. For each sold car, the government gains almost triple income compared to the manufacturer.

In order to clarify the situation, one can observe the price changes in the Euro currency. If we assume the manufacturer price of the car remain the same for each tax calculations (in this example manufacturer price is 19,107.67 EUR), one must pay 36,294.82 EUR for 1.6 L engine (can be seen on previous calculations), 52,688.12 EUR for 2.0 L engine, 73,662.80 EUR for 3.0 L engine in September 2020.

At this point, one can ask, 'why there are different rates of special consumption and motor vehicles tax calculations for different cars?'. Understanding this question will give us to enlighten the psychology of the government. In all economies of countries, the tax return is the major source of income. The special consumption tax entered into force on June 12, 2002, with the Law No. 4760 of the interests within the scope of the European Union harmonization process. The law covers luxury goods (white goods, jewelry, fur, automobile, etc.), substances harmful to human health (tobacco, alcohol, etc.). and environmentally harmful goods (fuel oil and oil derivatives, etc.). This tax arises from imported goods or when a product is delivered to its first buyer (Özel Tüketim Vergisi Kanunu, 2002) ${ }^{1}$. The $85.9 \%$ of the central budget revenues in Turkey is tax revenues (Strateji ve Bütçe Başkanllğı, 2020a). Moreover, the share of Special Consumption Tax in the budget income is $18.5 \%$. This ratio means an income of 162.6 billion TL. (Strateji ve Bütçe Başkanlığı, 2020b).

\section{Literature Review on HPM}

In last decade, it is seen that the Hedonic Regression Model is generally studied on price changes in the housing sector (Herath and Maier, 2010; Hülagü, Kızllkaya, Özbekler ve Tunar; 2016; Hill and Syed, 2016; Le, Cho and Kim, 2016; de Oliveira Santos, 2016). In these studies, it is understood that the characteristics of the settlements of the houses are relatively more investigated as price or rent determinants. There are also a few studies on the wine sector: (Herath and Maier, 2010; Cavallo, Caracciolo, Cicia, Giudice, 2017; Rebelo, Gomes, Gonçalves and Caldas, 2018; Hu and Baldin, 2018). In the wine sector, it was concluded that the development of distribution channels and the country of origin are important. Another sector where the hedonic model is applied is the automotive sector. Until 2000's automotive sector research focused on quality and fuel efficiency. After 2000's mileage had greater value than other internal characteristics.

Atkinson and Halvorsen (1984) applied a hedonic model to estimate the effects of gasoline price on automobile wear and fuel efficiency demand. The results show that the car has improved its specification in response to increases in gasoline price, which in turn significantly increases fuel efficiency.

Shiratsuka (1995), examined the variation of price changes in automobiles according to quality with a hedonic model. They found that quality-related price changes for different car models differ across segments and styles.

Berry, Kortum and Pakes (1996), focused on how economic variables and regulatory changes affect production costs and product characteristics in the automobile industry. They examined the impact of regulatory changes and gas price changes on automobile production costs and technological change. They

${ }^{1}$ Revision are being made in this law due to the requirements. The last revision was made on 30 August 2020. 
stated that the increases in gas prices led to technological change and that new car models increased the fuel efficiency.

Reis and Silva (2006) examined the effects of the quality change in new passenger cars in Portugal on the price index with a hedonic regression model for the years 1997-2001. Research findings revealed that the changes in the quality of new cars sold in Portugal during the period in question caused an annual average price increase of $4.8 \%$.

Pariete, Caemmerer and Baltas (2015) examined the effect levels on price differences in automobiles according to engine power, age, mileage, fuel type with a hedonic model. As a result of the analysis, it was determined that deviations from the expected average annual mileage affect the purchase of cars. It has been stated that the annual mileage may be a suitable criterion to measure the reliability of the automobile.

Mulalic and Rouwendal (2015) stated that the willingness of the automobile to pay per kilometer can be interpreted as a parameter of the utility function. It has been determined that the increase in the price of fuel (or changes in vehicle taxes) decreased the level of vehicle quality of the consumers.

Emmerling and Qari (2017) examined the effect of automobile purchasing decisions on long-term happiness. From 1991 to 2003 (the same individuals) they conducted a survey on a sample of 10,300 people. As a result of the research, it was found that the increase in happiness decreased by one third in the five years after the car was purchased.

\section{Theoretical Background and Model}

Hedonic Price Model (HPM) is based on Lancaster's (1960) consumer theory and Rosen's (1974) theoretical price model. Lancaster described the price of a good consists of the demand for its characteristics. The characteristics of a good are packaged as quality of a product and price equilibrium in a market occurs as the consumers and suppliers' desires coincide. Rosen's price model assumes all characteristics of a good is measured by a class of $z=\left(z_{1}, z_{2}, z_{3}, \ldots, z_{n}\right)$ where $z_{i}$ is the amount of ith characteristic in each good. The consumers choices define the package of characteristics of the good. Later, the price of a good is described of $p(z)=p\left(z_{1}, z_{2}, z_{3}, \ldots, z_{n}\right)$ simply means the price movements stem from hedonic factors rather than implicit ones.

According to HPM in competitive market conditions, the one fundamental assumption is the consumers preference is one only good at each time. The second one is on the market plane, where sellers and buyers meet, all participants are maximizing their utility according to characteristics of goods simply implies that no individual improve its optimal position. The reason behind this is the assumption that both producers and consumers of a good are the same. Thus, the price of a good is functioned as selfproduction process rather than final attributes.

The utility model proposed by Ladd and Suvannunt (1976) describes the total consumption Q for each good using characteristic $z=\left(z_{1}, z_{2}, z_{3}, \ldots, z_{n}\right)$ as a function of quantities of products consumed and characteristics of these products as:

$$
Q_{i}=f_{j}\left(q_{1}, q_{2}, \ldots, q_{n}, Z_{1 j}, Z_{2 j}, \ldots, Z_{n j}\right) \text { for } i=1,2, \ldots, n \text { and } j=1,2, \ldots, m
$$

where $Q_{i}$ refers to the total amount of ith product, $q_{i}$ is the quantity of ith product consumed, $Z_{i j}$ is the quantity of $j$ characteristic offered by product $i$ in the market.

The consumer's utility function is expressed as (Erdem \& Şentürk, 2009):

$$
U=f\left(q_{1}, q_{2}, \ldots, q_{n}, Z_{11}, Z_{21}, \ldots, Z_{n 1}, Z_{12}, Z_{22}, \ldots, Z_{n 2}, \ldots, Z_{1 m}, Z_{2 m}, \ldots, Z_{n m}\right)
$$

In here, the consumer is assumed to prefer a package of characteristics of a good to maximize its utility. The main constraint in maximizing process is budget of the consumer.

In our model, the characteristics of a good customized according to the characteristics of a vehicle. To be exact, there are several factors referred as a quality for a specific model of a brand. Our package of quality variables consists of equipment, year, mileage, transmission, fuel, color, and location of sold vehicle.

In detail, the price of a vehicle differs for each brand and its each model. Considering the specific model of specific brand, the one of most significant factors affecting price is the vehicle's equipment status. The equipment status, in here, refers to the package of internal instruments presented to consumers by the producers. Rather than one specific equipment of a vehicle such as seat heater, sunroof 
or fully digital dashboard, the bundle of these equipment eases the comparison between two distinct vehicles of same model. For a brand-new model vehicle, higher the equipment level, increases the price of the vehicle.

The second characteristic is assumed to be production year of the vehicle. The price of vehicle decreases the duration of the usage since every vehicle has a different but finite usage period. The consumer would prefer the newer vehicle among two identical ones besides the year, to maximize their utility for a certain amount of price. This results in the higher price of newer, lower price for older vehicles.

The third characteristic is assumed to be mileage. The mileage has similar effect on the price of a vehicle like the year. Both the mechanic and electronic parts of a vehicle worn out by the usage and the usage for this perspective is quantifiable by the mileage. The major issues may tend to occur with an increasing mileage. Besides the costs of periodical maintenance of the vehicle, the consumer may face with enormous repairing costs of these issues. The major issues preventing usage of the vehicle, may not occur during the lifespan of the vehicle until become a scrappage. But the possibility of this occurrence increases with the usage. Thus, the consumer will tend to spend more for a vehicle with lower mileage.

The fourth characteristic is defined as transmission. There are several types of transmissions presented to consumers by different type of brands. To able to compare different models, the transmission variable is defined as two different groups: manual and automatic. For a brand-new model, buyer faces with higher price if it prefers automatic transmission version of the vehicle rather manual one. This reflects also on the used car prices. The demand for a vehicle with an automatic transmission may be higher, which results in increase in price. However, for a hedonic perspective, the demand of vehicle does not influence price. The transmission variable is taken into consideration due to its higher cost in a brand-new one for a buyer.

The fifth characteristic is fuel type. There are several types of engines that consumes different types of sources. In the past, there were engines working mainly with gasoline. However, the scarcity of this nonrenewable resource forces manufacturers to produce different vehicles instead of gasoline. Later, the diesel engines were much more economical than gasoline, yet less environmentally. For environmental issues, the higher number of engines working with electricity are being produced with increasing technological developments. Today, some engines are fully electric, or hybrid which is a combination of electricity and gasoline. However, proliferation of electric engines has not been fully established yet. Rather than going into detail with the historical background of the engine types, we summarized our fuel type as gasoline and diesel because our sample brands do not have any hybrid or electric version of their vehicles or lack a sufficient number used ones.

The sixth characteristic is assumed to be the color of the vehicle. For a brand-new vehicle, the color type, whether metallic, pearlescent, etc., increases the purchasing price since it is considered optional. Thus, the vehicle's base color is generally one of solid paints such as solid white, solid black, etc. The used car market consists of cars with individual users, but the rate of used fleet cars in the market is also significantly high. Fleet cars are mainly used for business activities by firms, which means that these cars are expected to be cheap in cost reduction. Thus, most of the fleet cars have generally solid white or solid black color. The common belief is that white color is more maintenance friendly according to black one. In conclusion, if the potential sellable used car is in solid white, it is most likely to be one of the used fleet cars. Then the price of the used fleet cars should be lower than the individual used ones. From this perspective, the color of the used vehicle is assumed to influence the price.

The final characteristic is decided as the location of the seller. For a potential buyer, purchasing a used car is easier if it is in the same area. For two identical vehicles with the same price, the buyer will prefer the closest one. This observation results in an asymmetry in the supply of used cars according to location. The average income of citizens in the city may affect the price of the used car. The location of the seller may seem to be one of the implicit factors affecting the price, in here, it is assumed to be one of characteristics of the vehicle affecting its price independent from external ones. The average income of city citizens in Turkey is decided as the proxy of this variable. İstanbul and Ankara are two cities with the highest income (TR1 region) in 2020, according to TUIK. The cities with the lowest average income are stated as the 
cities in the TRC3 region, such as Batman, Mardin, Siirt, and Şırnak. Three income variables are dedicated as the dummy variable in our model.

In conclusion, our model is designed as follows:

$$
\begin{gathered}
\text { Price }=a_{1} \text { Equipment }+a_{2} \text { Year }+a_{3} \text { Milage }+a_{4} \text { Transmission }+a_{5} \text { Fuel }+a_{6} \text { White }+a_{7} \text { Black } \\
+a_{8} \text { Grey }+a_{9} \text { İstanbul }+a_{10} \text { Ankara }+a_{11} \text { Low Income }(\text { TRC } 3)+\text { constant }
\end{gathered}
$$

The equipment variable is coded as integers for each equipment level: lower (base), middle, higher, and highest (for some cases) levels. The year variable is reversely coded as integers for the manufacturing year of the vehicle, which is 1 for 2020, 2 for 2019, and 3 for 2018. The price and mileage variables are nominal values. Transmission, fuel, white, black, grey, İstanbul, Ankara, and low-income variables are coded as binary.

\subsection{Data and Methodology}

The used car prices and aforementioned characteristics of two specific models are used in application which are Renault Megane and Volkswagen Passat, since these two models are in the top 10 sold brandnew car models in 2020 in Turkey. The data is derived from "Sahibinden.com" which is one of used car advertisement online sites, in two different periods, one is in May 2020, and the other one is March 2021. Thus, the price differentiation within these two models and over a year has become viable. In May 2020, we obtained 765 used car advertisements of Renault Megane and 1,661 of Volkswagen Passat. In March 2021, we derived 2,757 used car advertisements of Renault Megane and 3,770 of Volkswagen Passat. All these cars have model years, either 2020, 2019, or 2018 for comparison purposes. Fuel consumption variable is constrained as gasoline and diesel because there are several cars with LPG (liquid petroleum gas) also in Megane, but there is almost none in Passat, which prevents the comparison between these two models. The hybrid engine (combination of electric and gasoline) and fully electric engine are not available in our sample. The mileage variable is in kilometers, and the price variable is in Turkish Lira. The incomerelated variables such as İstanbul, Ankara, and Low Income (TRC3 region cities) are decided through information represented by Turkish Statistical Institute (TUIK,2020).

In the application, the cross-sectional linear regression method is preferred. The used car prices in the two different periods are independently analyzed and reported separately for each model. Since there is no time period, but a cross-sectional dimension in our data, the cross-sectional linear regression with Ordinary Least Square (OLS) estimator is estimated for our variables. The linear regression assumes the linear relation between independent variables and dependent variable, which is in this case used car prices (Montgomery, Peck, \& Vining, 2021).

\subsection{Empirical Application and Findings}

The used car prices of two different models are analyzed with linear regression method according to Hedonic Price Model, and the empirical results are stated in the following table. The cross-sectional linear regression model with OLS estimator assumes that the variance of the unit values of the dependent variable will remain constant while the unit values of the independent variables change, and this assumption is called the constant variance (homoscedasticity) in the statistics literature (Albayrak, 2008). Thus, with the existence of heteroscedasticity between independent variables in our model, the robust variances were estimated for bias correction. The results are not represented separately since neither significance levels nor coefficient values of independent variables have changed.

Table 3. Used Car Prices Cross-Sectional Linear Regression Test Results

\begin{tabular}{|c|c|c|c|c|}
\hline \multirow{2}{*}{$\begin{array}{c}\text { Independent } \\
\text { variables }\end{array}$} & March 2021 & May 2020 & March 2021 & May 2020 \\
\cline { 2 - 5 } & Megane & Megane & Passat & Passat \\
\cline { 2 - 5 } & Price & Price & Price & Price \\
\hline \multirow{2}{*}{ Equipment } & $\mathbf{2 9 , 8 2 1 . 2 2 * * *}$ & $\mathbf{1 7 , 9 4 2 . 7 1 1 ^ { * * * }}$ & $\mathbf{6 3 , 9 4 2 . 7 2 * * *}$ & $43,135.653^{* * *}$ \\
& $(600.942)$ & $(788.492)$ & $\mathbf{( 7 9 1 . 1 7 8 7 )}$ & $(670.156)$ \\
\hline
\end{tabular}


What is Happening to Used Car Prices in Turkey? Evidence From Hedonic Price Model (Hpm)

\begin{tabular}{|c|c|c|c|c|}
\hline Year & $\begin{array}{c}-\mathbf{1 7 , 8 3 0 . 5 7 9 * * *} \\
(760.519)\end{array}$ & $\begin{array}{c}-11,433.478 * * * \\
(896.764)\end{array}$ & $\begin{array}{c}-\mathbf{2 6 , 5 1 6 . 1 6 * * *} \\
(1,126.199)\end{array}$ & $\begin{array}{c}-\mathbf{1 4 , 9 0 8 . 7 1 5 * * *} \\
(997.047)\end{array}$ \\
\hline Mileage & $\begin{array}{c}\mathbf{- 0 . 4 7 2 * * *} \\
(0.019)\end{array}$ & $\begin{array}{c}-\mathbf{0 . 2 3 1 5 * * *} \\
(0.018)\end{array}$ & $\begin{array}{c}-.4702718 * * * \\
(.0326813)\end{array}$ & $\begin{array}{c}-\mathbf{- 0 . 3 8 0 * * *} \\
(0.033)\end{array}$ \\
\hline Transmission & $\begin{array}{c}\mathbf{7 , 2 4 7 . 7 7 0} * * * \\
(2,431.810)\end{array}$ & $\begin{array}{c}\mathbf{2 1 , 4 0 5 . 4 3 9 * * *} \\
(2,492.192)\end{array}$ & $\begin{array}{c}\mathbf{1 5 , 4 2 3 . 6 3 * * *} \\
(3,161.472)\end{array}$ & $\begin{array}{c}\mathbf{1 6 , 9 6 6 . 8 4 3 * * *} \\
(2,120.260)\end{array}$ \\
\hline Fuel & $\begin{array}{c}\text { 21,837.254*** } \\
(1,060.702)\end{array}$ & $\begin{array}{c}\mathbf{1 0 , 3 5 2 . 1 6 4 4 * * *} \\
(2,190.849)\end{array}$ & $\begin{array}{l}\mathbf{4 5 , 3 9 3 . 6 * * *} \\
(1,423.011)\end{array}$ & $\begin{array}{c}\text { 27,195.999*** } \\
(1,320.891)\end{array}$ \\
\hline White (color) & $\begin{array}{c}-4,346.705 * * * \\
(979.680)\end{array}$ & $\begin{array}{c}-\mathbf{7 2 9 . 3 6 6} \\
(1,046.952)\end{array}$ & $\begin{array}{l}-3,124.857^{*} \\
(1,686.881)\end{array}$ & $\begin{array}{c}\mathbf{- 3 6 5 . 0 9 3} \\
(1,570.007)\end{array}$ \\
\hline Black (color) & $\begin{array}{c}\mathbf{1 1 9 . 6 5 1} \\
(2,515.502)\end{array}$ & $\begin{array}{l}-1,841.862 \\
(2,248.696)\end{array}$ & $\begin{array}{l}\mathbf{1 , 7 4 3 . 7 3 2} \\
(2,080.441)\end{array}$ & $\begin{array}{c}\mathbf{- 1 7 4 . 3 7 2} \\
(2,023.286)\end{array}$ \\
\hline Grey (color) & $\begin{array}{c}\mathbf{- 3 0 4 . 2 8 9} \\
(1,293.339)\end{array}$ & $\begin{array}{l}\mathbf{1 , 0 6 3 . 4 9 3} \\
(1,452.696)\end{array}$ & $\begin{array}{l}-1,749.222 \\
(2,163.386)\end{array}$ & $\begin{array}{c}\mathbf{- 5 , 2 6 5 . 6 8 6 * * *} \\
(2,030.911)\end{array}$ \\
\hline İstanbul & $\begin{array}{c}-7,610.564 * * * \\
(827.230)\end{array}$ & $\begin{array}{c}-4,271.327 * * * \\
(851.821)\end{array}$ & $\begin{array}{l}\mathbf{- 2 , 3 4 3 . 1 5 5 *} \\
(1,421.351)\end{array}$ & $\begin{array}{l}\mathbf{1 , 2 2 0 . 3 4 9} \\
(1,202.062)\end{array}$ \\
\hline Ankara & $\begin{array}{l}-1,991.274 * \\
(1,197.016)\end{array}$ & $\begin{array}{c}-712.854 \\
(1,326.866)\end{array}$ & $\begin{array}{l}\mathbf{4 , 1 4 8 . 5 3 9 * *} \\
(2,080.795)\end{array}$ & $\begin{array}{l}\mathbf{4 , 1 0 0 . 3 7 4 * *} \\
(1,797.608)\end{array}$ \\
\hline $\begin{array}{l}\text { Low Income } \\
\text { (TRC3) }\end{array}$ & $\begin{array}{l}-4,079.267 \\
(4,236.829)\end{array}$ & $\begin{array}{l}-4,904.680 \\
(5,510.082)\end{array}$ & $\begin{array}{l}2,511.736 \\
(3,953.891)\end{array}$ & $\begin{array}{l}-6,215.515 \\
(3,829.398)\end{array}$ \\
\hline Constant & $\begin{array}{c}\mathbf{2 3 8 , 1 6 2 . 2 9 7 * * *} \\
(2,892.207)\end{array}$ & $\begin{array}{c}154,822.633 * * * \\
(2,537.479)\end{array}$ & $\begin{array}{c}333,263.4 * * * \\
(4,212.961)\end{array}$ & $\begin{array}{c}\mathbf{2 2 1 , 3 0 5 . 5 0 5 * * *} \\
(3,476.474)\end{array}$ \\
\hline $\begin{array}{l}\text { Observation } \\
\text { Model } R^{\wedge} 2\end{array}$ & $\begin{array}{l}2,757 \\
0.7408\end{array}$ & $\begin{array}{c}765 \\
0.6927\end{array}$ & $\begin{array}{c}3770 \\
0.7513\end{array}$ & $\begin{array}{c}1,661 \\
0.7969\end{array}$ \\
\hline $\begin{array}{c}\text { Model F-statistics } \\
\text { Model P-value }\end{array}$ & $\begin{array}{l}717.148 \\
0.0000\end{array}$ & $\begin{array}{l}157.553 \\
0.0000\end{array}$ & $\begin{array}{l}1036.22 \\
0.0000\end{array}$ & $\begin{array}{l}593.145 \\
0.0000\end{array}$ \\
\hline
\end{tabular}

Note: The values in the table show the coefficient of the relevant variable, the values in the brackets show the standard deviation value of the relevant coefficient. *,** and *** show the $10 \%, 5 \%$ and $1 \%$ significance level, respectively.

According to test results, the adjusted $\mathrm{R}^{2}$ of each model is significantly high, which shows success in estimating used car prices. The equipment, year, mileage, transmission, fuel variables, and constant term for each model are statistically significant. The color variables and variables that represent the location of the seller are less successful in explanation.

To be more specific about the test results and for a more detailed explanation, assume an individual searched a used car to purchase and assume it decided to purchase one of Volkswagen Passat model cars today. The constant term reveals that the price of Passat with 2020 model year, base level equipment, manual transmission and gasoline engine is 333,263 Turkish Liras (TL). In case of budget constraints, individual may pay 26,516 TL less for 2019 model and additional same amount for each older car. If 
individual decides to prefer higher level of equipment, it faces with 63,942 TL charges for each higher level. Similarly, if it prefers automatic transmission instead of manual, it must pay additional 15,423 . The cost of diesel engine rather than gasoline one will be 45,393 TL. The white color of same car will be 3,124 TL cheaper, and additional 2,343 TL discount will be made if the car is being sold in Istanbul. The price of this car will be 4,148 TL higher than average if it is located in Ankara. Finally, the price decreases by about 4,720 TL for each 10k kilometers.

If individual decided to purchase Renault Megane with 2020 model year, base level equipment, manual transmission and gasoline engine, the price would be 238,162 Turkish Liras (TL). Similar to Passat, individual may pay 17,830TL less for 2019 model and additional same amount for each older car. If an individual decides to prefer a higher level of equipment, it faces 29,821TL charges for each higher level. Similarly, if it prefers automatic transmission instead of manual, it must pay additional 7,247. The cost of diesel engine rather than gasoline one will be 21,837 TL for Megane. The white color of same car will be 4,346TL cheaper, and additional 7,610 TL discount will be made if the car is being sold in İstanbul. The price of this car will be 1,991 TL lower than average if it is located in Ankara. Finally, the price decreases about 4700 TL for every 10k kilometers, similar to Passat.

To compare the today prices of Passat and Megane, one must pay higher for Passat model car and each level of equipment. The diesel version of Megane $(\% 8,8)$ is much cheaper than Passat $(\% 13)$ according to each model's Fuel/Price ratio. The white color Megane is also priced lower than white color Passat in ratios. The black and grey colors are not statistically significant for both models. The Megane in İstanbul is also apparently cheaper than the Passat in same city. While the price of Passat in Ankara is higher than average, the price of Megane in Ankara is below average. Low-income cities are also not statistically significant for both models.

To compare today's prices with last year's prices, the main observation from the table is that both Passat and Megane models had lower prices than today's versions. The price of Passat with 2020 model year, base level equipment, manual transmission and gasoline engine was 221,305 Turkish Liras (TL) in May 2020. In case of budget constraints, individual might pay 14,908 TL less for 2019 model and additional same amount for each older car. If individual decided to prefer higher level of equipment, it would face with 43,135 TL charges for each higher level. Similarly, if it preferred automatic transmission instead of manual, it had to pay additional 16,966. The cost of diesel engine rather than gasoline one would be 27,195 TL. The white color of same car would be 3,124 TL cheaper and additional 4,100 TL charge would be made if the car were being sold in Ankara. Finally, the price decreased about 3800 TL for each 10k kilometers.

If individual decided to purchase Renault Megane with 2020 model year, base level equipment, manual transmission and gasoline engine, the price would be 154,822.633 Turkish Liras (TL) in May 2020. Similar to Passat, individual might pay 11,433 TL less for 2019 model and additional same amount for each older car. If individual decided to prefer higher level of equipment, it would face with 17,942 TL charges for each higher level. Similarly, if it preferred automatic transmission instead of manual, it had to pay additional 21,405. The cost of diesel engine rather than gasoline one would be 10,352 TL for Megane. The color variables for Megane are not significant. The car would be 4,271 TL cheaper if it were being sold in İstanbul. Finally, the price decreased about 2300 TL for each 10k kilometers similar to Passat.

\section{Conclusion}

In recent years, it has been seen that used car prices have increased significantly in Turkey. In addition to the course of car prices, The Turkish Lira has inflated against the Euro currency after the first occurrence of the Covid-19 case in Turkey. The general attitude during the high inflation period is just leaving the local currency, which means, in this case, foreign currency or gold. Both gold and Euro showed an excessive increase in value during the pandemic. The aim of this research is that establish which components caused this remarkable increase.

There are several issues related to the used car industry in Turkey. The first is the price of used cars. Used car prices have been increasing steadily for the last ten years. The two main reasons for this move are brand new automobile prices and a high inflation environment. In an environment of high inflation, 
Turkish society preferred to invest in gold during the pandemic period. However, the increase in prices for both new and used cars is higher than the gold yield. Despite the economic crisis due to the global health problem, bankruptcy of many companies, and increasing unemployment, sales of new and used automobiles continue at rising prices. During the pandemic, most individuals increased their wealth due to the increase in the price of their possession, while the purchasing power decreased due to high inflation.

The used car prices and the aforementioned characteristics of two specific models are used in the application: Renault Megane and Volkswagen Passat. These two models are in the top 10 sold brand-new car models in 2020 in Turkey. The two different periods (2020 and 2021) are independently analyzed and reported separately for each model. The 2018-2019-2020 model car variables were used as data for 2020 and 2021. When the data was analyzed, the most significant observation is that the prices of 2020 model cars are higher in 2021 (even though they were one year old in March 2021) compared to May 2020. To clarify this observation, the brand-new cars sold outside the branches of the brand are defined only by their mileage in Turkey. This simply means that there may be brand-new cars with zero mileage but 2017 model year.

Data has a cross-sectional dimension; thus, the cross-sectional linear regression with Ordinary Least Square (OLS) estimator is estimated for variables. According to test results, each model's equipment, year, mileage, transmission, fuel variables, and constant term are statistically significant. The price is increasing with the equipment level, diesel engine, and automatic transmission preferences, and it is decreasing with mileage. The color variables and variables that represent the location of the seller are less successful in explanation. For a general conclusion, white and grey colors are decreasing the prices of March 2021 and May 2020, respectively.

Researchers have mainly focused on the housing sector, automotive sector, and wine sector in the last decade. Until the 2000's automotive sector researchers focused on quality and fuel efficiency. After the 2000 's mileage has become the most significant than other variables, our model results are consistent with previous studies.

Future research could investigate automobiles in different segments in the model; to examine the effects of different variables like different production settles can be suggested. Different hedonic factors and implicit factors can also be investigated.

\section{References}

Albayrak, A. S. (2008). To the Least Squares Technique in the Presence. Afyon Kocatepe Üniversitesi, I.I.B.F. Dergisi, 10(2), 111-134.

Atkinson, S. E., \& Halvorsen, R. (1984). A new hedonic technique for estimating attribute demand: an application to the demand for automobile fuel efficiency. The Review of Economics and Statistics, 417-426.

Automotive Distributor Association (2020), Automotive Distributors Association Market Retail Sales. Retrieved on February 15, 2021, from http://www.odd.org.tr/web_2837_1/sortial.aspx?linkpos=1\&target=categorial1\&type=36\&primary_id=

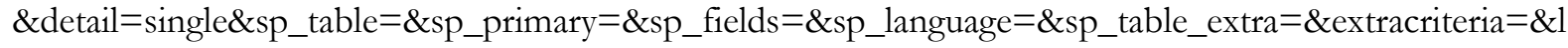
anguage_id=1\&search_fields=\&search_values $=$

Barrero, J. M., Bloom, N., \& Davis, S. J. (2020). Covid-19 is also a reallocation shock (No. w27137). National Bureau of Economic Research.

Berry, S., Kortum, S., \& Pakes, A. (1996). Environmental change and hedonic cost functions for automobiles. Proceedings of the National Academy of Sciences, 93(23), 12731-12738.

Bexter, R. (2020). Used car prices surge during COVID-19 pandemic as drivers move away from transport and new models. Retrieved on February 15, 2021 from 9news website: https://www.9news.com.au/national/used-car-prices-queensland-increasing-public-transport-abandonednew-cars-slump/d7e3e5c8-f749-43f2-bb59-a31e7f071e06

Bimbo, F., Bonanno, A., Liu, X., \& Viscecchia, R. (2016). Hedonic analysis of the price of UHTtreated milk in Italy. Journal of Dairy Science, 99(2), 1095-1102.

Bloomberg HT. (2020). Altın Fiyatı. Retrieved on January 14, 2021, from https://www.bloomberght.com/altin 
Branch, B. (1977). A tax loss trading rule. the Journal of Business, 50(2), 198-207.

Cavallo, C., Caracciolo, F., Cicia, G., \& Del Giudice, T. (2018). Extra-virgin olive oil: are consumers provided with the sensory quality they want? A hedonic price model with sensory attributes. Journal of the Science of Food and Agriculture, 98(4), 1591-1598.

Cavallo, C., Caracciolo, F., Cicia, G., \& Del Giudice, T. (2018). Extra-virgin olive oil: are consumers provided with the sensory quality they want? A hedonic price model with sensory attributes. Journal of the Science of Food and Agriculture, 98(4), 1591-1598.

Central Bank of The Republic of Turkey. (2020). Central Bank of The Republic of Turkey. Retrieved on January 14, 2021, from https://evds2.tcmb.gov.tr/index.php?/evds/serieMarket/\#collapse_2

Dargay, J. M. (2001). The effect of income on car ownership: evidence of asymmetry. Transportation Research Part A: Policy and Practice, 35(9), 807-821.

De Oliveira Santos, G. E. (2016). Worldwide hedonic prices of subjective characteristics of hostels. Tourism Management, 52, 451-454.

Emmerling, J., \& Qari, S. (2017). Car ownership and hedonic adaptation. Journal of Economic Psychology, 61, 29-38.

Erdem, C., \& Şentürk, I. (2009). A hedonic analysis of used car prices in Turkey. International Journal of Economic Perspectives, 3(2), 141-149.

Friedman, M. (2007). Price theory. Transaction Publishers.

Gössling, S., Scott, D., \& Hall, C. M. (2020). Pandemics, tourism and global change: a rapid assessment of COVID-19. Journal of Sustainable Tourism, 1-20.

Herath, S., \& Maier, G. (2010). The hedonic price method in real estate and housing market research: a review of the literature. Institute for Regional Development and Environment (pp. 1-21). Vienna, Austria: University of Economics and Business.

Hill, R. J., \& Syed, I. A. (2016). Hedonic price-rent ratios, user cost, and departures from equilibrium in the housing market. Regional Science and Urban Economics, 56, 60-72.

Hu, L., \& Baldin, A. (2018). The country of origin effect: a hedonic price analysis of the Chinese wine market. British Food Journal.

Hülagü, T., Kızllkaya, E., Özbekler, A. G., \& Tunar, P. (2016). A hedonic house price index for Turkey. Central Bank of the Republic of Turkey Working Papers, 16(03).

Ladd, G. W., \& Suvannunt, V. (1976). A Model of Consumer Goods Characteristics. American Journal of Agricultural Economics, 58(3), 504-510. https://doi.org/10.2307/1239267

Lambin, J. J. (1970). Optimal allocation of competitive marketing efforts: an empirical study. The Journal of Business, 43(4), 468-484.

Lancaster, K. J. (1960). A New Approach to Consumer Theory. The Journal of Political Economy, 74(2), $132-157$.

Lee, G., Cho, D., \& Kim, K. (2016). The modifiable areal unit problem in hedonic house-price models. Urban Geography, 37(2), 223-245.

Lieske, S. N., van den Nouwelant, R., Han, J. H., \& Pettit, C. (2021). A novel hedonic price modelling approach for estimating the impact of transportation infrastructure on property prices. Urban Studies, 58(1), 182-202.

Lorde, T., Jacob, J., \& Weekes, Q. (2018). Price-setting behavior in a tourism sharing economy accommodation market: A hedonic price analysis of AirBnB hosts in the caribbean. Tourism Management Perspectives, Vol. 30, (2019): pp. 251-261.

Lucas, R., \& Stokey, N. (2011). Liquidity crises. Unpublished manuscript, University of Chicago.

Montgomery, D. C., Peck, E. A., \& Vining, G. G. (2021). Introduction to linear regression analysis. John Wiley \& Sons.

Morioka, T., Fujita, T., \& Yoshida, N. (1996). Performance and shortcomings of typical environmental pollution control programs for automobile traffic in Kobe city and surrounding areas. Social cost evaluation of noise pollution by hedonic price method. Science of the total environment, 189, 99-105.

Motorlu Taşıtlar Vergisi Kanunu. (1963). 197 Saylı Motorlu Taşıtlar Vergisi Kanunu. Retrieved on October 8, 2020, from https://www.mevzuat.gov.tr/MevzuatMetin/1.5.197.pdf 
Mulalic, I., \& Rouwendal, J. (2015). The impact of fixed and variable cost on automobile demand: Evidence from Denmark. Economics of Transportation, 4(4), 227-240.

Otokokpit. (2020). Volkswagen Otomobil Fiyat Listesi. Retrieved on Mar 31, 2021, from https://www.otokokpit.com/volkswagen-kasim-2019-fiyat-listesi-aciklandi/

Özel Tüketim Vergisi Kanunu. (2002). 4760 Say1lı Özel Tüketim Vergisi Kanunu. Retrieved on October 12, 2020, from https:/ / www.mevzuat.gov.tr/MevzuatMetin/1.5.4760.pdf

Park, S., Choi, G. J., \& Ko, H. (2020). Information technology-based tracing strategy in response to COVID-19 in South Korea-privacy controversies. Jama.

Philkotse. (2019). philkotse.com. Retrieved on February 15, 2021, from https:/ /philkotse.com/marketnews/market-analysis-downfall-in-world-car-sales-for-the-first-half-2019-5298

Ramya, N., \& Ali, S. M. (2016). Factors affecting consumer buying behavior. International journal of applied research, 2(10), 76-80.

Rebelo, J., Lourenço-Gomes, L., Gonçalves, T., \& Caldas, J. (2019). A hedonic price analysis for the Portuguese wine market: Does the distribution channel matter?. Journal of Applied Economics, 22(1), 4059.

Reis, H. J., \& Silva, J. S. (2006). Hedonic prices indexes for new passenger cars in Portugal (19972001). Economic Modelling, 23(6), 890-908.

Reuters. (2020). Reuters. Retrieved on February 15, 2021, from https://www.reuters.com/article/usgermany-economy-wages-idUSKBN1JM1AS

Rosen, S. (1974). Hedonic prices and implicit markets: Product differentiation in pure competition. Journal of Political Economy, 82, 34-55. https://doi.org/10.1086/260169

Statista. (2020). Average price (including tax) of passenger cars in the EU in 2015 and 2019, by country. Retrieved on February 12, 2021, from https://www.statista.com/statistics/425095/eu-car-salesaverage-prices-in-by-country/

Strateji ve Bütçe Başkanlığı. (2020a). Türkiye Cumhuriyeti Merkezi Yönetim Bütçesi Aylık Bütçe Gerçekleşmeleri. Retrieved on February 20, 2021, from http://www.sbb.gov.tr/merkezi-yonetim-butcesiaylik-gerceklesmeleri/

Strateji ve Bütçe Başkanlı̆̆ı. (2020b). Türkiye Cumhuriyeti Vergi Gelirleri. Retrieved on February 20, 2021, from https://www.sbb.gov.tr/vergi-gelirleri/

Szczesny, J. (2020). Car Sales Losing Momentum as COVID Cases Rise. Retrieved from The Detroit Bureau website: Retrieved on February 14, 2021, from https://www.thedetroitbureau.com/2020/07/carsales-losing-momentum-as-covid-cases-rise/

The World Bank. (2020). GDP per capita (current US\$). Retrieved on February 10, 2021, from https://data.worldbank.org/indicator/NY.GDP.PCAP.CD?name_desc $=$ false

Trading Economics. (2020). Trading Economics. Retrieved on February 20, 2021, from https://tradingeconomics.com/country-list/gdp

TUIKK. (2020). Gelir ve Yaşam Koşulları Araştırması Bölgesel Sonuçları. Retrieved on March 24, 2021, from https://data.tuik.gov.tr/Bulten/Index?p=Income-and-Living-Conditions-Survey-Regional-Results2020-37405

Wang, X. Y., \& Zhang, P. (2008). Disclosure and Insider Trading Profiteering Strategy- Case Study Using a Sample of Six Corporations in a Share Marketplace. Journal of Management Case Studies, 3.

World Health Organization. (2020). World Health Organization. Retrieved on February 4, 2021, from https://www.who.int/news/item/27-04-2020-who-timeline---covid-19 